\section{An Imaginary Open Letter to the U.S. Commission on Ocean Policy}

\section{Commissioners,}

As you read this, your report to the U.S. Congress, President and populace is being finalized. The numbers and statistics, alone, are impressive: thousands of hours of testimony, hundreds of pounds of papers and reports, countless staff meetings, and millions of miles of travel by you and the witnesses who have come before you. In short, your effort to collect data, information and knowledge has been Herculean ... we want to make sure it's not also Sisyphean.

We are the potential implementers of the recommendations that you may develop. You have already demonstrated a deep and careful understanding of many of those issues that we deal with on a daily basis: resource management and sustainability, hazard mitigation, governance of the oceans and coastal lands, ecosystem and public health (just to name a few), and the research and education that form the foundation of the implied capabilities therein.

You have worked well with all of us in developing the basis for your recommendations. How can we continue this relationship through the implementation of what we are sure will be some fundamental and sage directions for the future? We, the signatories, represent a set of diverse organizations with powerful tools to effect change. We sponsor research and operations, we write program requirements, we execute and enforce laws, we establish policies, we create standards, we convince policy-makers, and we market products. In short, we solve problems.

As we await your final report, many of us wonder how to position ourselves to implement your recommendations. Your charge requires that you deliver a report, but we are asking you to do more. We are asking you to work with us in establishing the roadmap for implementation. You'd be surprised how many of us are eager to take your ideas and run with them. How do we do this? Wait to receive the report in the mail, and then go our independent ways to develop solutions? I think not. Instead, a carefully crafted campaign to develop an implementation plan for your recommendations seems in order. Work with us on this. Many of us have pulled out a clean sheet of paper, and sharpened our pencils. With all due respect, your final sets of recommendations are only as good as our ability to implement them, and we're ready whenever you are to discuss the way ahead.

Signed,

- Federal, State, regional bureaucrats

- Academic researchers

- Members of non-governmental organizations

- Industry executives and stockholders

- International community of oceanographers www.tos.org

\section{EDITOR}

Richard W. Spinrad

U.S. Naval Observatory

3450 Massachusetts Avenue, NW Washington, DC 20392-5421 USA

(202) 762-1697 Fax: (202) 762-1025 richard.spinrad@navy.mil

\section{ASSISTANT EDITOR Elizabeth J. Tirpak magazine@tos.org}

ASSOCIATE EDITORS

Gregg J. Brunskill

Australian Institute of Marine Science PMB No. 3, Townsville, M.C. Queensland 4810, Australia

(61) 747534481 Fax: (61) 747725852 g.brunskill@aims.gov.au

Ellen R.M. Druffel

Department of Earth System Science

222 Roland Hall University of California Irvine, California 92697-3100 USA (949) 824-2116 Fax: (949) 824-3256 edruffel@uci.edu

Charles H. Greene

Director, Ocean Resources and Ecosystems Program Department of Earth \& Atmospheric Sciences Cornell University 2130 Snee Hall

Ithaca, New York 14853-2701

(607) 255-5449 Fax: (607) 254-4780 chg2@cornell.edu

James Syvitski

Director, Institute of Arctic and Alpine Research University of Colorado at Boulder 1560 30th Street, Campus Box 450 Boulder, Colorado 80309-4050 USA (303) 492-7909 Fax: (303) 492-6388 james.syvitski@colorado.edu

Peter Wadhams Scott Polar Research Institute University of Cambridge Lensfield Road

Cambridge CB2 1ER England +44 1223-336542 Fax: +44 1223-336549 pw11@phx.cam.ac.uk

DESIGN/PRINTING

Corporate Press

403 Brightseat Road

Landover, Maryland 20785 USA 